\title{
Managerial Ability and Sustainable Financial Performance
}

\author{
Nova Novita \\ \{nova.novita@ibs.ac.id\} \\ STIE Indonesia Banking School
}

\begin{abstract}
The banking industry plays a vital role in supporting sustainable economic development. Although indirectly, banks can stimulate the success of sustainable business processes, by adding requirements to environmentally friendly business processes in the financing approval. On the other hand, banks are also required to maintain their sustainable financial performance. This research aims to test the influence of managerial ability on the sustainability of financial performance. This research used listed commercial banks from four ASEAN countries. The data obtained from the website of the stock exchange of Indonesia, Malaysia, Thailand, and Singapore. Managerial ability is measured by using the Managerial Ability Score, which is generated by using Data Envelopment Analysis. The sustainability of financial performance proxied by sustainable growth rate. This research used a random effect model to test the hypotheses. The result shows that managerial ability does not affect sustainable financial performance. This finding indicates that high-interest rates dominate the overall bank performance so that it cannot explain the impact of resource management performance on sustainable financial performance. The findings of this research alone can be a reflection of the need to improve management capabilities in managing resources efficiently.
\end{abstract}

Keywords: Banking, Data Envelopment Analysis, Managerial Ability, Sustainability, Sustainable Financial Performance.

\section{Introduction}

Businesses are growing more aggressive and put companies under pressure to maintain their sustainability of success in the future. Sustainability is defined as meeting our needs today without compromising future generations' ability to meet their need [1]. As the backbone of the national economy, the financial industry can indirectly accelerate sustainable development in a country. Commercial banks present a critical function in allocating financial resources to individual and economic activity not only for today but also tomorrow [2]. In 
addition to its vital functions, banks themselves are also required to run sustainable businesses, including maintaining the sustainability of their financial performance. Because the sustainability of bank financial performance will have an impact on the economy of a country, conversely, bank failures can cause a crisis in a country.

A standardized framework for sustainable and responsible banking was issued in July 2019, namely Principles for Responsible Banking (PRB) under the United Nations Environment Programme Finance Initiative (UNEP FI). The PRB aim to align the banking sector to the Sustainable Development Goals (SDGs) and the goals of the Paris Agreement. PRB will promote banks to report their social and environmental impact and engage with their customers and stakeholders to promote sustainability [3].

Support from the government of ASEAN finance ministers and central bank governors have also confirmed the importance of sustainable finance and requested financial institutions to include Environmental, Social and Governance (ESG) factors into their business strategy. The following countries have issued sustainable financing regulations [3]. State Bank of Vietnam issued directive $03 / \mathrm{CT}-\mathrm{NHNN}$ on promoting green credit growth and environmental social risks management in credit granting activities on March 2015. The Association of Banks in Singapore issued guidelines on responsible financing in October 2015 (updated in June 2018). The Thai Bankers’ Association issued Sustainable banking guidelines - responsible lending in August 2019. Financial Services Authority of Indonesia (OJK) issued the OJK Regulation No. 51/POJK.03/2017 on the Implementation of Sustainable Finance for Financial Services Institutions, Issuers, and Public Companies, The regulation came into force in 2019. Bank Negara Malaysia issued the Value-based Intermediation 
Financing and Investment Impact Assessment Framework (consultative document) for Islamic banking in October 2018.

Apart from the regulation of the importance of sustainable practices, many researchers still questioning whether sustainability has a positive impact on financial performance $[4,5,6,7]$. A company's success in benefiting from sustainable practices is influenced by individual ability in management [8]. Also, management who can integrate sustainability into corporate strategy will be more able to obtain sustainability benefits, especially in terms of financial performance compared to companies that do not [9]. These management capabilities can be measured by the ability to allocate company resources efficiently. Moreover, sustainability requires carefulness in utilize opportunities while allocating resources efficiently so that the cost of sustainable practice is lower than the benefits.

Managerial ability define as the knowledge, skills, and experience, which is often tacit, residing with and utilized by manage [10]. Superior managers can read trends better, predict demand more accurately, and invest in more valuecreating projects, therefore connecting themselves with a better financial performance [11]. The more able managed bank will have higher loan quality [12]. The higher of management capability, the better on mitigating the risk and its impact on sustainable financial performance [13].

This paper is the first research that directly tests the managerial ability impact on sustainable financial performance. Research of [13] specifically tests the effect of cash flow risk management on the company's sustainable financial performance in Sri Lanka. The number of benefits received from sustainability practices will be influenced by managerial ability. This research is expected to 
contribute to explaining the managerial capabilities of banks in four ASEAN countries, which are presumed to be a portrait of the ASEAN region. Furthermore, the findings of this research are expected to be input for regulators in formulating policies, especially regarding improving bank efficiency.

\section{Literature Review and Hypothesis Development}

\subsection{Resource Based Theory (RBT)}

Resource-Based Theory (RBT) is a theory that explains that resources are a source of competitive advantage for an organization [14]. According to [14] firm resources include all assets, capabilities, organizational processes, firm attributes, information, and knowledge controlled by a firm that enables the firm to conceive of and implement strategies that improve its efficiency and effectiveness. A firm is said to have a sustained competitive advantage when it is implementing a value-creating strategy not simultaneously being implemented by any current or potential competitors and when these other firms are unable to duplicate the benefits of this strategy. Based on this theory, it can be concluded that companies that can manage their resources efficiently will be able to achieve competitive advantage and sustainable financial performance.

\subsection{Managerial Ability}

Managerial ability reflects the knowledge, skills, and experience, which is often tacit, residing with and utilized by managers [10]. There are three types of ability, namely firm-specific, industry-specific, and general components [15]. General ability represents knowledge, skills, or experience that produce value for any firm that makes use of them. Firm-specific ability is least mobile and 
unique to a context, while the industry-specific ability is somewhat transferable because of its relevance to firms within the industry. From a strategic perspective, managerial ability derives from two primary sources: domain expertise and resource expertise. Domain expertise refers to managers' understanding of the industry context and the firm's strategies, products, markets, task environments, and routines. Resource expertise manifests through experience with resource management processes. Specifically, it represents the ability of managers to select and configure a firm's resource portfolio, bundle resources into distinctive combinations, and deploy them to exploit opportunities in specific contexts.

Managerial ability in this research measured by managers' efficiency, which shows ability in transforming corporate resources to revenues that developed by [16]. Quantitative managerial ability consists of a multitude of revenuegenerating resources: cost of inventory, general and administrative expenses, fixed assets, operating leases, past research and development (R\&D) expenditures, and intangible assets. The more able managers will have a better understanding regarding technology and industry trends, strong predict product demand, invest in higher-value projects, and manage their employees more efficiently than less able managers. In short, more able managers can generate higher revenue for a given level of resources and conversely.

In the banking context, some adjustments were made to the measurement of managerial ability. The output is calculated using total revenue, while the input component uses, total deposits, total fixed assets, labour costs and intangible assets. These input and output components then processed by using Data 
Envelopment Analysis to obtain a Managerial Ability Score (MAScore). A score of close to 1 indicates that the company can use its resources efficiently.

\subsection{Sustainable Performance}

Sustainability define as the development of an economic sector that complements the needs of the present generation but does not sacrifice opportunities and capabilities for future generations [5]. The banking sector is the backbone of a national economy. Although it uses fewer natural resources, emissions, and waste in comparison with the manufacturing or mining companies, there is much evidence in the literature that sustainability and going green will lead the service sectors toward profitability. Southeast Asian countries are particularly endangered to the consequences of climate change that increase the degradation of natural resources caused by unsustainable agriculture and fishing practices, mining and infrastructure developments in the region. Since risks associated with climate change, natural capital degradation, and cost of insurance, commercials banks will be effected through the reduction in credit quality and collateral value of loans [17].

In Southeast Asia, financial regulators and governments identify the critical role played by the finance sector. In April 2019, ASEAN finance ministers and central bank governors declared that "sustainable finance plays an important role to improve our economic efficiency, prosperity, and competitiveness while protecting and promoting ecological systems, and enhancing cultural diversity and social well-being" and encouraged "the banking community of ASEAN to gradually adopt the principles of sustainable finance into business practices [17]. Besides being a catalyst in the progression of green business, the bank itself should do the same so that the bank management's ability will be tested 
with this challenge. If the managerial ability is strong, the bank will be able to achieve sustainable financial performance. Because in current business practice, strategies regarding creating sustainable income, cost controlling and building stakeholder trust along with risk management are the most important things compared to earning profit from a traditional perspective [13].

\subsection{Hyphoteses Development}

Resources Based Theory pronounces that managerial ability is one source of competitive advantage that enables companies to obtain superior performance through effectiveness and efficiency. This managerial ability will be reflected in the aspects of planning until controlling, reliable risk management capabilities and carefulness in investing as well as in expanding market share. This ability will affect company performance, as evidenced in the following studies:

A premise of the resource-based view of the firm - that managers are a potential source of value creation for the firm were investigated by [10]. The theory was tested by using data from professional sports teams, regarding the effects of managerial ability, human resource stocks, and managers' actions on resource value creation. This study shows that managers differ concerning their ability to manage resources, and these variations help explain why some firms create more value from their resources than others do. Managers with superior ability have a more substantial effect on resource productivity and also plays a vital role in determining how firms synchronize their resources to create a performance advantage.

The role of unobservable managerial ability on bank lending behaviour has been tested by [12]. The empirical results suggest that more able managed banks 
produce a higher amount of loans. The result holds regardless of the size of the banks and time. We also find that more ably managed banks have higher loan quality.

A Research tried to answer why the previous studies find the positive or insignificant effect of the CEO's abilities on firm performance [18]. Using the U.S. publicly traded firms drawn from the BoardEx and EXECUXOMP database during from 1992 to 2014, the results show that the fit of the CEO's generality or specialist ability with firm strategy matters on firm performance and risk. This study computes a discrete strategy composite measure to construct firm strategy types, such as Prospector or Defender and use the CEO's resume to construct an index of general skills that are transferable across firms and industries. The results show that generalist CEOs are more suitable for prospectors than specialist CEOs. Firm performance is much better when specialist CEOs work for Defenders. Although the firm performance is better too for the generalist CEOs who fit for the Prospect strategy, the firm's risk is up too. The result suggests that firms need to consider their chosen business strategy to recruit and select CEOs.

How executives impact resource allocation by investigating the three underpinnings of dynamic managerial capabilities (DMCs) as antecedents of related business diversification (RBD) and how they interact with firm resources to influence RBD were described by [19]. The collective impact of managerial human capital, managerial social capital, and managerial cognition within the board of directors of English Premier League clubs were analyzed. The key findings are following, DMCs are highly relevant for RBD, although their underpinnings show different effect directions. Also, firm resources play an 
influential role for RBD. Finally, DMCs significantly moderates the relationship of firm resources and RBD, but in different directions.

The efficiency performance of conventional and Islamic rural banks in Indonesia, specifically, Bank Perkreditan Rakyat (BPR) and Bank Pembiayaan Rakyat Syariah (BPRS) has been tested by [20]. Using a DEA approach, the results indicate that both BPR and BPRS are inefficient in terms of the intermediation role but efficient in production. Furthermore, the Tobit estimation shows that these results are positively affected by location and the capital adequacy ratio (CAR). Rural banks operating in cities tend to have a higher level of efficiency than those who are not. Moreover, the higher the capital, the more efficient both Islamic and conventional rural banks in terms of production and intermediation.

According to the prediction of resources based theory and previous studies, this research hypothesizes:

H1: Managerial Ability Will Increase Sustainability Financial Performance

\section{Research Method}

\subsection{Data and Sample}

The population in this study uses the entire banking industry in ASEAN 4 (Indonesia, Malaysia, Thailand, and Singapore) during the 2015-2019 period, consisting of 60 companies. The sampling method of this research is nonprobability sampling using a purposive sampling method. 


\subsection{Operational Variables}

Variabel dependen is Sustainable Financial Performance, measured by Sustainable Growth Rate, calculated as followed:

$$
\mathrm{SGR}=\text { ROE }(1-\text { Div. PayoutRatio })
$$

The sustainable growth rate (SGR) defined as the maximum growth rate that a business can afford without having to increase financial leverage or without looking outside finance solution [13]. The SGR calculation assumes that if a company wants to maintain a target capital structure of debt and equity, keep a static dividend payout ratio, and increase sales as quickly as the organization can.

The independent variable is Managerial Ability, measured using the efficiency score using the following formula:

$$
\max _{v m} \theta=\frac{\sum_{i-1}^{s} u_{i} y_{i k}}{\sum_{j-i}^{m} v_{j} x_{j k}}
$$

Note :

$\Theta$ : Score of Bank Efficiency k.

Ui : weighted output I of bank k.

Yik : sum of output I of bank k from $\mathrm{i}=1$ to $\mathrm{k}$

$\mathrm{Vj}$ : weighted input $\mathrm{j}$ of bank $\mathrm{k}$.

$\mathrm{Xjk}$ : sum of input $\mathrm{j}$ of bank $\mathrm{k}$ from $\mathrm{j}-1$ to $\mathrm{m}$

Output components in this case are: total revenue, while the input component consists of: Deposit fund, Labor Costs, Total Fixed Assets, Goodwill and Intangible Assets, thus the formula becomes:

$$
\text { MAScore }=\frac{\text { Total Revenue }}{\text { Deposit fund }+ \text { Labor Costs }+ \text { Fixed Assets + Intangible Assets }}
$$


We used Data Envelopment Analysis to determine the efficiency score. This research use bank size, leverage, Gross Domestic Product and Economic Growth as control variables.

The research hypothesis is estimated using the following equation:

$$
\text { SGR }_{i t}=\beta_{0}+\beta_{1} \text { MAScore }{ }_{i t}+\beta_{2} \text { Size }_{i t}+\beta_{3} \operatorname{Lev}_{i t}+\beta_{4} \operatorname{LnGDP}_{i t}+\beta_{5} \text { EcoGrow }_{i t}+\varepsilon_{i t}
$$

Explanations:

SGR : Sustainability Growth Rate

MAScore : Managerial Ability

Size $\quad$ : Bank Size

Lev : Leverage

LnGDP : : Gross Domestic Product

EcoGrow : Economic Growth

The mathematical equation in this research is estimated using Eviews 9 and using a random-effects model. Even though there are heteroscedasticity and autocorrelation problems in the estimation model, these problems had been treated. 


\section{Result and Discussion}

\subsection{Descriptive statistics}

\section{Tabel 4.1 Descriptive statistics}

\begin{tabular}{lcccccc} 
& SGR & SCORE & SIZE & LEV & LNGDP & ECOGROW \\
\hline Mean & 0.068 & 0.116 & 29.439 & 0.820 & 8.798 & 4.485 \\
Median & 0.066 & 0.002 & 28.706 & 0.863 & 8.717 & 5.020 \\
Maximum & 0.162 & 1.000 & 34.887 & 0.919 & 11.096 & 5.900 \\
Minimum & -0.012 & 0.0002 & 24.696 & 0.265 & 8.125 & 0.980 \\
Std. Dev. & 0.033 & 0.281 & 2.908 & 0.110 & 0.787 & 1.079 \\
Skewness & 0.298 & 2.479 & 0.260 & -3.938 & 1.783 & -1.998 \\
Kurtosis & 3.248 & 7.564 & 1.705 & 19.561 & 5.638 & 6.832 \\
Observations & 174 & 174 & 174 & 174 & 174 & 174 \\
\hline
\end{tabular}

Based on Table 4.1 above, it can be concluded that the Sustainability Growth Rate variable in the sample banks is relatively high. In other words, the ability of the sample bank to survive without additional debt or funding from external parties is considerably good. Variation of Sustainability Growth Rate data is low, which is means that the sustainable capabilities of the sample bank are relatively indifferent.

Managerial Ability (MAScore) data shows that the ability of bank management in managing its resources is relatively low. In other words, the sample bank management has not been able to maintain its resources efficiently. It can be seen from the average value of MAScore, which is relatively far from value one as explained earlier that the more MAScore approximated 1, the more efficient the management handling the company's resources. The variation in managerial ability is relatively high, which is means that some banks can achieve maximum efficiency scores, while others have low-efficiency scores. 
Bank size data shows that the sample banks are classified as banks with significant assets. Besides, there is a low-level variation of bank size, so the sample in this research is homogeneous. In terms of debt, in general, the sample banks are classified as having high debt ratios, although they are yet at a healthy level. The variation in debt level data is moderately small, so the data tends to be homogeneous.

Table 4.2 Regression Results

\begin{tabular}{lrrrr}
\multicolumn{1}{c}{ Variable } & \multicolumn{1}{c}{ Koefisien } & Std. Error & \multicolumn{1}{c}{ t-Statistic } & \multicolumn{1}{c}{ Prob. } \\
\hline C & -0.365051 & 0.054705 & -6.673037 & 0.0000 \\
MASCORE & 0.012562 & 0.010751 & 1.168449 & 0.2443 \\
SIZE & 0.009416 & 0.001137 & 8.281234 & $0.0000^{* * *}$ \\
LEV & 0.106885 & 0.019783 & 5.402955 & $0.0000^{* * *}$ \\
LNGDP & 0.0098 & 0.004102 & 2.388818 & $0.018 * *$ \\
ECOGROW & -0.004687 & 0.001705 & -2.748655 & $0.0066^{* * *}$ \\
R-squared & 0.367585 & Mean dependent var & 0.028633 \\
Adjusted R-squared & 0.348763 & S.D. dependent var & 0.025298 \\
S.E. of Regression & 0.020391 & Sum squared resid & 0.069856 \\
F-statistic & 19.52968 & Durbin-Watson stat & 1.430017 \\
Prob(F-stastistic) & 0.000000 & & &
\end{tabular}

From the regression results in table 4.2 above, it can be interpreted that the model can explain the variation of Sustainability Financial Performance of $36.76 \%$. Other variables outside this research model explain the rest (63.24\%).

This research failed to confirm the positive influence of managerial ability on financial performance sustainability. A possible explanation for this result is higher level of sustainable growth rate is affected by the higher interest rates, not because of efficiency in resource management. As described in the descriptive statistic before, on average, the sample in this research is classified 
as a low level of efficiency bank. Furthermore, we compare the Net Interest Margin (NIM) data in the following five ASEAN countries. Net Interest Margin (NIM) is the ability of banks to obtain interest income (from the difference between credit and deposit interest).



Figure 1. The Graph of ASEAN Bank Net Interest Margin Source: https://lokadata.beritagar.id/: DBS Singapore and OJK Research

It can be seen from the graph that Indonesian bank charge the highest interest rate compare with others. Net Interest Margin (NIM) is the ability of banks to obtain interest income (from the difference between credit and deposit interest). Should be noted, the number of samples from Indonesia cover 55\% of total sample. In other words, the inefficiency of banks in Indonesia probably affects the results of this research.

The bank size variable in this research determined to have a positive effect on financial performance sustainability. The higher the size of the bank, the greater ability of banks to create financial performance sustainability. In this research, an increase in total assets will increase financial performance sustainability by 
0.009416. Another interesting finding is the positive impact of debt on financial performance sustainability. In overall, the ratio of debt bank sample is below one, which is considered fair. This finding explains that sample banks can manage their debts into productive debt.

Gross Domestic Product as Macro variable shows a positive effect, that the higher of GDP, the better ability of banks to promote sustainable finance. In contrast, economic growth, in this case, has a negative effect on financial performance sustainability. One possible explanation that in the period 20152019 there was a downward trend in economic growth in the four sample countries. This fact certainly affects the bank's performance, which is very closely related to the economic environment in a country.

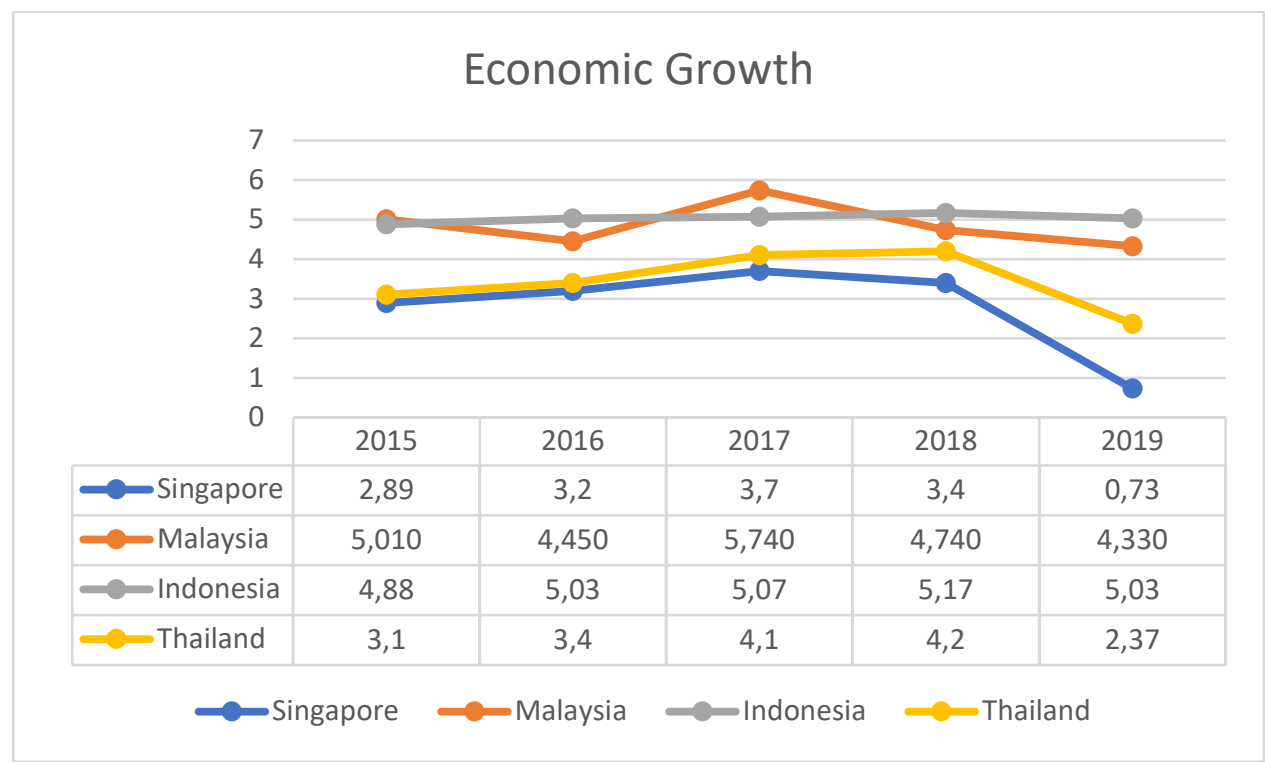

Figure 2: Graph of Economic Growth 


\section{Implications}

The implication of the research is, in general, the efficiency issue exists in ASEAN banks. For this reason, continuous works are needed to improve managerial capacity in the individual bank. Regulators need to pay more attention to the factors determining the efficiency of banks because as a government partner, banks that able to operate efficiently can perform the catalytic function of a country's economic development. For banks, the findings of this research alone can be a reflection of the need to improve management capabilities in managing resources efficiently especially for Indonesian banks, so they do not rely too high on higher interest rate.

\section{Conclusions, Limitations, and Suggestions}

This research aims to examine the impact of managerial ability on the sustainability financial performance of ASEAN banks. The research shows that there is no influence on managerial ability on financial performance sustainability. This research has several limitations. First, this research only use financial perspective as the measurement of sustainable financial performance. The future research is expected to be able to combine this sustainability issue using proxies of environmental and social aspects. Second, the use of debt as a control variable is less informative for the banking industry. So, the future research better-using Loan to deposit ratio rather than debt to equity ratio

\section{Acknowledgements.}

The Author would like to thank the support received regarding data collection, in particular to Elfady Krisna Bayu, M. Resa Perdiansyah, Ananda Uly I.R, Andhini Laila Gita, Amelia Rahmaniar, and Virlyana Sandra Stefany S. 


\section{References}

1. Our Common Future: Report of the World Commission on Environment and Development". UN Documents. n.d. Web. Retrieved 26 Jul 2020. < http://www.un-documents. net/ocf-02.htm>

2. Yip, A., \& Bocken, N. Sustainable Business Model Archetypes for the Banking Industry. Journal of Cleaner Production; 2017. https://doi.org/10.1016/j.jclepro.2017.10.190

3. Chen Ted Kin, J. S. and N. T. Sustainable Banking in ASEAN. World Wide Fund for Nature, Gland, Switzerland; 2019.

4. Ali, M., Denizel, M., \& Durak, D. Addressing endogeneity in the causal relationship between sustainability and fi nancial performance. Intern. Journal of Production Economics, 2019, 210(January 2013), 56-71; https://doi.org/10.1016/j.ijpe.2019.01.016

5. Alshehhi, A., Nobanee, H., \& Khare, N. The Impact of Sustainability Practices on Corporate Financial Performance: Literature Trends and Future Research Potential. Sustainability 2018, 10, 494; https://doi.org/10.3390/su10020494

6. Hussain, N., Rigoni, U., \& Cavezzali, E. Does it pay to be really good? Looking inside the black box of the relationship between sustainability performance and financial performance. Corporate Social Responsibility and Environmental Management published by ERP Environment and John Wiley \& Sons Ltd, 2018. https://doi.org/10.1002/csr.1631

7. Nizam, E., Ng, A., Dewandaru, G., \& Nagayev, R. The impact of social and environmental sustainability on financial performance: A global analysis of the banking sector. Journal of Multinational Financial Management, 2019, 49, 35-53. https://doi.org/10.1016/j.mulfin.2019.01.002

8. Eide, A. E., Saether, E. A., \& Aspelund, A. An investigation of leaders' motivation, intellectual leadership, and sustainability strategy in relation to 
Norwegian manufacturers' performance. Journal of Cleaner Production, 2020, 254, 120053. https://doi.org/10.1016/j.jclepro.2020.120053

9. Przychodzen, W., \& Przychodzen, J. Bridging the gap: How sustainable development can help companies create shareholder value and improve financial performance. Business Ethics: A Eur Rev, 2017; 26: 1-17. https://doi.org/10.1111/beer.12135

10. Holcomb, T. R., Jr, R. M. H., Connelly, B. L. Making the Most of What You Have : Managerial Ability as a Source of Resource Value Creation. Strategic Management Journal, 2009, 30: 457-485. https://doi.org/10.1002/smj.747

11. Lee, C., Wang, C., Chiu, W., \& Tien, T. Managerial ability and corporate investment opportunity. International Review of Financial Analysis, 2018, 57 (February), 65-76. https://doi.org/10.1016/j.irfa.2018.02.007

12. Vinh, X., Hoang, T., Pham, A., Ngoc, T., \& Ngoc, H. Managerial Ability and Bank Lending Behavior. Finance Research Letters, 2020, (March), 101585. https://doi.org/10.1016/j.frl.2020.101585

13. Wickramasinghe, M. B. Cash Flow Risk Management Practices on Sustainable Financial Performance in Sri Lanka. International Journal of Arts and Commerce, 2017, 6(8), 57-69.

14. Barney, J. B., \& Barney, J. B. The Resource-Based Theory of the Firm. Organization Science, 1991,Vol. 7, No. 5.

15. Richard P. Castanias and Constance E. Helfat. Managerial Resources and Rents. Journal of Management, $1991 \quad 17$ : 155. https://doi.org/10.1177/014920639101700110

16. Demerjian, P. R., Baruch Lev, \& Mcvay, S. E. Quantifying Managerial Ability: A New Measure and Validity Tests. Management Science, 2012, 58(7), 1229-1248. https://www.jstor.org/stable/41499554

17. Augoyard, Sylvain, Ted Kin Chen, Jeanne Stampe. Sustainable Banking 
Regulations in Asean - Raising the Bar. WorldWide Fund for Nature, Gland, Switzerland, 2019.

18. Cheng,Teng Yuan, Yue-Qi Li, Yu-En Lin, Hsiang-Hsuan Chih. Does the Fit of Managerial Ability with Firm Strategy Matters on Firm Performance? Journal of Asian Finance, Economics and Business, 2020 Vol 7, No 4, 9 19. doi:10.13106/jafeb.2020.vol7.no4.9.

19. Holzmayer, Florian, Sascha L. Schmidta.Dynamic managerial capabilities, firm resources, and related business diversification-Evidence from the English Premier League. Journal of Business Research, 2020, 117, 132-143. https://doi.org/10.1016/j.jbusres.2020.05.044.

20. Wasiaturrahma, Raditya Sukmana, Shochrul Rohmatul Ajija, Sri Cahyaning Umi Salama,Ahmad Hudaifah. Financial performance of rural banks in Indonesia: A two-stage DEA approach. Heliyon 6, 2020, e04390. https://doi.org/10.1016/j.heliyon.2020.e04390

21. https://lokadata.beritagar.id/: DBS Singapore and OJK Research 